\title{
濡れ性の悪い水平平板上面に付着する気泡の 大きさと形状
}

\author{
水野 義照*・井上 洋*2・園山 希*・井口 学*3 \\ Size and Shape of a Bubble on the Upper Surface of a Horizontal Plate \\ of Poor Wettability \\ Yoshiteru Mizuno, Hiroshi Inoue, Nozomu Sonoyama and Manabu Iguchi
}

Synopsis : Air was gradually supplied through a small vertical hole to form a single bubble on the upper surface of a horizontal flat plate of poor wettability. The bubble grew with an increase in the supplied air volume. The growing behavior of the bubble was observed with a CCD camera. The shape and size of the bubble on the upper surface of the plate were determined as functions of the surface tension, contact angle, densities of liquid and gas based on an energy equation for the bubble. Furthermore, the maximum bubble volume which allows a bubble to stay on the upper surface of the plate was predictable from the energy equation and a force balance equation for the bubble.

Key words : steelmaking; wettability; bubble attachment; contact angle; energy equation; force balance equation.

\section{1. 緒言}

精錬プロセスや溶融還元プロセスにおけるフォーミング の発生は鋼の品質, 生産性の向上などに対して大きな弊害 となっている。その発生機構 ${ }^{1-3)}$ は脱炭反応による $\mathrm{CO}$ ガ ス発生に起因するとされており，フォーミングの抑制に関 してはスラグ層へのコークス，石炭の投入 ${ }^{4)}$ やスラグの高 温化による粘度低減, 表面張力増加 ${ }^{5)}$, さらに超低周波の 音波印加 ${ }^{6)}$ などの研究が報告されている。とくに小川ら7 は炭材と溶融金属との濡れ性が悪いことによる微細COガ ス気泡の炭材への付着現象がフォーミング抑制に有効であ ることを見出した。

著者らは，このような濡れ性に起因する気泡の固体への 付着現象を利用した溶融金属中の微細気泡の除去方法を確 立すべく，付着機構に関する基礎的検討 ${ }^{8)}$ を行ってきた。 すなわち, 水一空気系気泡噴流中へ濡れ性の悪い円柱を水 平に浸漬したときの, 気泡が円柱表面へ付着する現象を観 察し, 円柱に捕捉された気泡が互いに接触, 吸収し合って 大きくなり, 最終的に円柱の上端部から離脱するときの気 泡の大きさと形状を気泡に対するエネルギー式9) から予測 した。なお気泡形状には簡便なモデルを適用した。予測值 と実測值は比較的よく合っており，エネルギー式の妥当性 が確認された。しかしながら, 気泡周辺に存在する液体の 流れの影響や接触角が異なる場合への適用性は評価できて いない。
そこで本研究では，まず液体の流れによる流体抵抗や気 泡どうしの接触, 吸収に伴う影響を無視できる条件, すな わち静止液体中に浸漬した水平平板上にゆっくりと単一気 泡を生成させた場合について, 前報 ${ }^{8)} に$ 示したエネルギー 式で気泡の大きさと形状の予測がどの程度可能であるのか を従来のラプラスの方法 ${ }^{10-12)}$ と比較しつつ明らかにした。 また, 水一空気系だけでなく, 水銀一空気系での評価も 行つた。

\section{2. 実験装置および測定方法}

水中に浸漬した濡れ性の悪い平板上に付着する空気気泡 の観察に用いた装置の概要を Fig. 1に示す。以下この系を 水-空気系と呼ぶ。幅 $250 \times 10^{-3} \mathrm{~m}$, 奥行き $100 \times 10^{-3} \mathrm{~m}$, 深さ $150 \times 10^{-3} \mathrm{~m}$ のアクリル製透明容器に $140 \times 10^{-3} \mathrm{~m}$ の深 さまで水を満たし，表面に撥水処理を施した平板を水面か らの距離が $40 \times 10^{-3} \mathrm{~m}$ の位置に水平に置いた。平板はアク リル樹脂の表面をパラフィンでコーティングした接触角 $\theta_{C}=104^{\circ}$ のものと黄銅板にフッ素樹脂系コーティングを施 した接触角 $\theta_{C}=116^{\circ}, 131^{\circ}$ ののを用いた。本研究では $90^{\circ} \leqq \theta_{C} \leqq 180^{\circ}$ のと濡れ性が悪いと定義する。

ステッピングモーター駆動のシリンジにより平板に開け た直径 $1.0 \times 10^{-3} \mathrm{~m}$ の（Fig. 1 の $A$ 部参照）へ空気を送り 込み，平板上に気泡を付着させる。シリンジの一定流量押 出しにより, 平板上の気泡は徐々に大きくなり, ある大き

平成 12 年 5 月 2 日受付 平成 12 年 8 月 22 日受理 (Received on May 2, 2000; Accepted on Aug. 22, 2000)

* 北海道大学大学院生 (Graduate Student, Hokkaido University, North 13 West 8 Kita-ku Sapporo 060-8628)

* 2 北海道大学学生 (Undergraduate Student, Hokkaido University)

*3 北海道大学大学院工学研究科 (Graduate School of Engineering, Hokkaido University) 

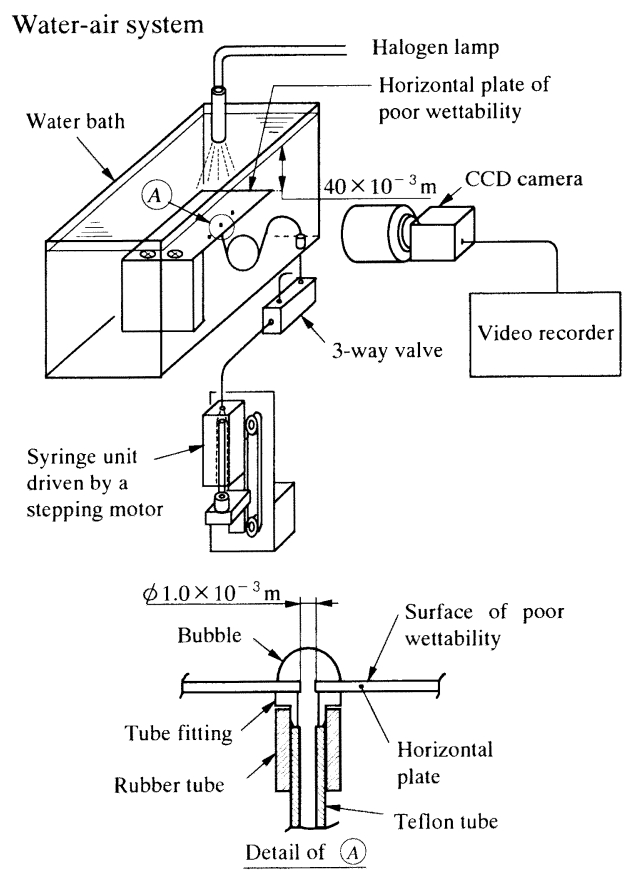

Fig. 1. Schematic diagram of experimental apparatus for water-air system.

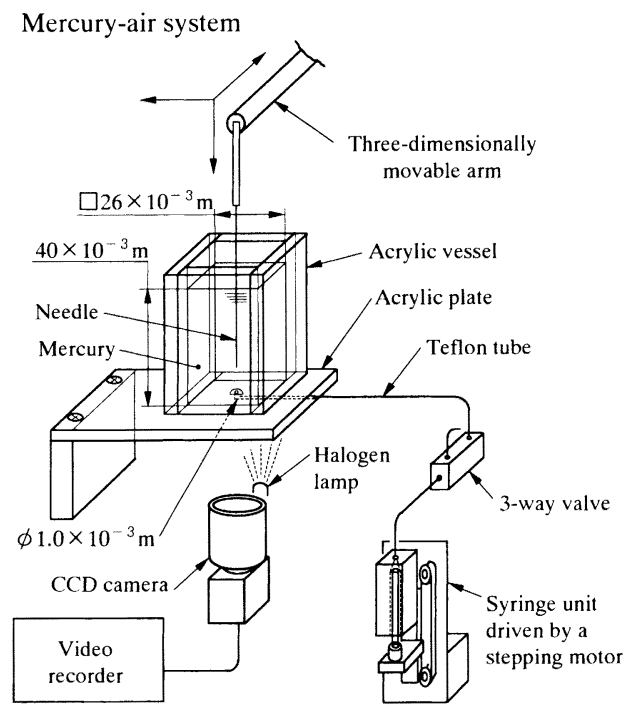

Fig. 2. Schematic diagram of experimental apparatus for mercury-air system.

さと形状になると平板から離脱する。気泡の成長と離脱の 様子を CCD カメラで水平方向から撮影し，その画像を測 長して気泡の二次元形状を求めた。また, 気泡の体積は二 次元形状をもとに積分して求めた。シリンジの平均押出し 流量は $2.1 \times 10^{-9} \mathrm{~m}^{3} / \mathrm{s}$ であり，モーターの 1 ステップあたり の押出し量は $0.21 \times 10^{-9} \mathrm{~m}^{3}$ とした。これによって離脱前の 気泡の形状，寸法に及ぼす空気の慣性力の影響は無視でき る。測定中の液温は $25^{\circ} \mathrm{C} \pm 2{ }^{\circ} \mathrm{C}$ とた。

Fig. 2 には水銀中で濡れ性の悪い平板上に付着する空気 気泡の観察に用いた装置の概要を示す。以下この系を水銀 一空気系と呼ぶ。幅と奥行きが $26 \times 10^{-3} \mathrm{~m}$, 深さ
$50 \times 10^{-3} \mathrm{~m}$ のアクリル製透明容器に $40 \times 10^{-3} \mathrm{~m}$ の深さまで 水銀を満たした。水銀のアクリル板に対する接触角 $\theta_{C}$ は $130^{\circ}$ であった。水-空気系装置と同方法, 同条件にて容器 の底板に開けた直径 $1.0 \times 10^{-3} \mathrm{~m}$ の へ空気を送り込み， 底板上に気泡を付着させる。気泡と底板との界面を容器の 底方向から CCD カラで撮影し，その画像を測長して平 板上における気泡の幹の直径 $D_{B}$ を求めた。一方, 気泡の 高さ $H_{B}$ は, 三次元方向に移動可能なアームに取り付けた 針の先端を気泡の頂点付近に接触させる方法で測定した。 すなわち, 針の先端が容器の底板上面および気泡の頂点に 位置する時の鉛直方向座標の差を読み，気泡の高さとした。 気泡の高さの最小読み取り長さは $0.01 \times 10^{-3} \mathrm{~m}$ であるが, 手動のため測定誤差は約 $\pm 3 \%$ あ゙あ。気泡の体積はシリ ンジの空気押出し量とした。

気泡寸法の測定值は同条件で撮影した基準スケールを用 いて実寸法へ換算した。CCDカメラはマクロレンズ付き のため画像分解能は $0.04 \times 10^{-3} \mathrm{~m} /$ 画素と高く, 幾何光学的 画像ひずみは約 $\pm 1 \%$ 以下であった。よって画像による気 泡寸法の測定䛊差は約 $\pm 4 \%$ 以下と考えられる。

\section{3. 実験結果と考察}

\section{$3 \cdot 1$ エネルギー式に基づく気泡の形状予測}

静止液体中で固体に付着できる気泡の大きさと形状を求 める方法には, 気液界面内外の圧力バランスから数值的に 求める方法 ${ }^{10-12)}$ (ラプラス法）と気泡がもつエネルギーの 最小化から求める方法 ${ }^{9)}$ (ポテンシャル法) が考えられる。 前者については，佐野らの溶鉄中の浸漬ノズルからの気泡 生成に関する研究 ${ }^{13)}$ でその詳細が考察されている。また, 李ら ${ }^{10)}$ により，液滴に関しては回転楕円体形状を仮定す ることによって前者と後者は同じ結果を導き出すことが報 告されている。しかしながら，ラプラス法は気泡界面の局 所的な圧力バランスを取り扱うのに対し，ポテンシャル法 は気泡の全体的なエネルギーを取り扱っている点に違いが ある。気泡除去操作を考える上では，今後，液の流れによ る流体抵抗や気泡どうしの接触・吸収による効果を考慮す る必要がある。その場合，ラプラス法ではこれらの影響を 組み込むことは難しいが，ポテンシャル法では例えば流体 抵抗による影響を近似的に $C_{D} A_{P} \rho_{n} \bar{u}_{n}{ }^{2} z_{G} / 2$ で考慮できる。 ここで $C_{D}$ は抵抗係数， $A_{P}$ は流れに垂直な平面への気泡の 投影面積， $\rho_{n}$ は水の密度， $\bar{u}_{n}$ は水の速度， $z_{G}$ は気泡の底 面から気泡の重心位置までの距離である。このような理由 から本研究で著者らはポテンシャル法を採用した。さらに 気泡形状に簡便なモデルを適用することによる予測計算の 簡略化に配慮した。

$3 \cdot 1 \cdot 1$ 形状予測の方法

Fig. 3 に示すように, 濡れ性の悪い固体へ付着した気泡 には浮力による位置のエネルギー，表面張力によって気泡 


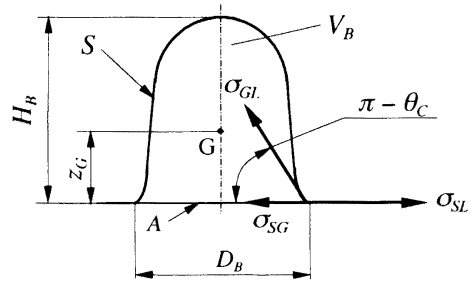

G : Center of gravity

Fig. 3. Explanation of symbols in energy equation for bubble.

(a) Model 1

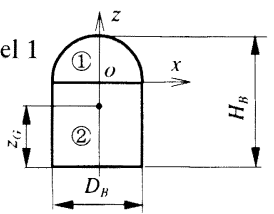

(b) Model $\left.\left.2 d^{1}\right|^{z}-(r+d / 2)\right\}^{2}+z^{2}=r^{2}$
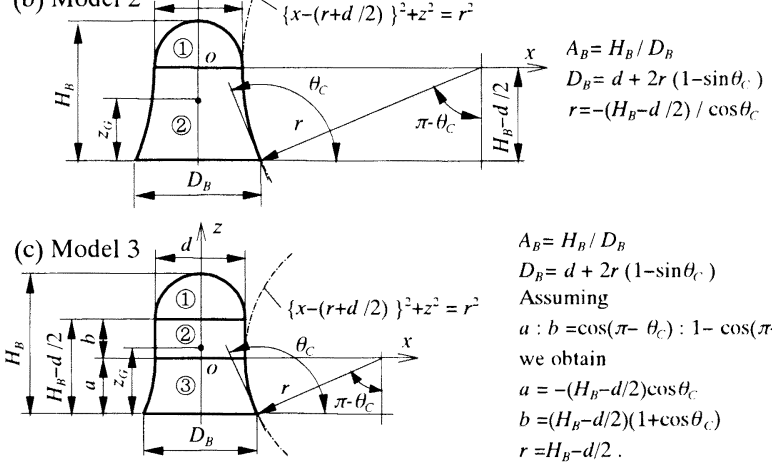

$A_{B}=H_{B} / D_{B}$

$D_{B}=d+2 r\left(1-\sin \theta_{C}\right)$

Assuming

$a: b=\cos \left(\pi-\theta_{C}\right): 1-\cos \left(\pi-\theta_{C}\right)$,

we obtain

$a=-\left(H_{B}-d / 2\right) \cos \theta_{C}$

$b=\left(H_{B}-d / 2\right)\left(1+\cos \theta_{C}\right)$

$r=H_{B}-d / 2$.

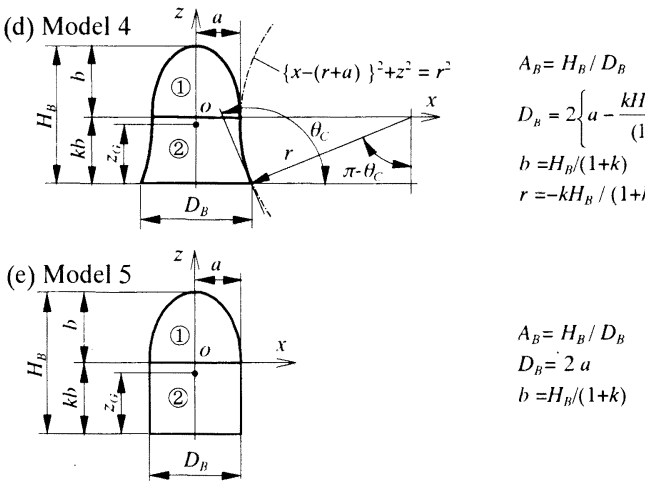

Fig. 4. Models applied to bubble shape.

を縮めようとする表面エネルギー，円柱に気泡を引き止め ておこうとする界面エネルギーの3つが働くが，平板上に 置かれた液滴に働くエネルギーに関する式 ${ }^{14)}$ を参考にす れば，気泡に対するエネルギー $E^{9)}$ は次式で与えられる。

$$
E=-\left(\rho_{L}-\rho_{g}\right) g V_{B} z_{G}+\sigma_{G L} S+\sigma_{G L} A \cos \theta_{C}
$$

ここで $\rho_{L}$ と $\rho_{g}$ は液体と気体の密度, $g$ は重力加速度, $V_{B}$ は気泡体積, $z_{G}$ は円柱表面から気泡の重心位置までの距 離, $\sigma_{G L}$ は気液界面での表面張力, $S$ は気液界面積, $A$ は 固気界面積である。なお, 気泡を円柱に付着させるように 働く力の方向, すなわち下向きを正にとっている。ある気 泡体積 $V_{B}$ に対してエネルギー $E$ が極小となるとき気泡は
最も安定すると考え，そのときの形状をこの体積における 予測形状とした。具体的には $3 \cdot 1 \cdot 2$ 以降で述べるように, まず気泡形状を仮定し，気泡体積 $V_{B}$ を与えたときに $E$ が 極小となるアスペクト比 $A_{B}\left(=H_{B} / D_{B}\right)$ を求めた。そのとき の $V_{B}$ と $A_{B}$ から $H_{B}$ と $D_{B}$ が求められる。

$3 \cdot 1 \cdot 2$ 気泡形状のモデル化

本研究では Fig. 3 のような実測気泡形状に Fig. 4 に示す 5 種類のモデルを適用した。これらのモデルは平板上にお ける気泡の幹の直径 $D_{B}$, 高さ $H_{B}$ および接触角 $\theta_{C}$ を与える ことにより， $V_{B}, z_{G}, S, A$ が比較的簡単に計算できる。以下 に各モデルの説明と $V_{B}, z_{G}, S, A$ の計算式を示す。

（1）モデル1（Fig. 4(a) 参照）：円柱の上に半球が乗った形 状。「付録-1：式 ( 2 ), ( 3 ), ( 5 ) の導出」を参照。

$$
\begin{aligned}
& V_{B}=\pi D_{B}^{2} H_{B} / 4-\pi D_{B}^{3} / 24 \cdots \\
& S=\pi D_{B} H_{B} \\
& A=\pi D_{B}{ }^{2} / 4 \\
& z_{G}=\left(D_{B}{ }^{2}-8 D_{B} H_{B}+24 H_{B}{ }^{2}\right) /\left(48 H_{B}-8 D_{B}\right)
\end{aligned}
$$

(2) モデル2（Fig. 4(b)参照)：円錐台の上に半球が乗った 形状。「付録 -2 : 式 (6) (9) の導出」を参照。

$V_{B}=\left(\pi / 12 \cos ^{3} \theta_{C}\right)\left\{d^{3} \cos ^{3} \theta_{C}+24\left(H_{B}-d / 2\right)^{3} \cos \theta_{C}\right.$

$-12 d\left(H_{B}-d / 2\right)^{2} \cos ^{2} \theta_{C}+3 d^{2}\left(H_{B}-d / 2\right) \cos ^{3} \theta_{C}$

$-4\left(H_{B}-d / 2\right)^{3} \cos ^{3} \theta_{C}-12\left(H_{B}-d / 2\right)^{3} \sin \theta_{C} \cos \theta_{C}$

$+6 d\left(H_{B}-d / 2\right)^{2} \sin \theta_{C} \cos ^{2} \theta_{C}-12\left(H_{B}-d / 2\right)^{3} \sin ^{-1}\left(\cos \theta_{C}\right)$

$\left.+6 d\left(H_{B}-d / 2\right)^{2} \cos \theta_{C} \sin ^{-1}\left(\cos \theta_{C}\right)\right\}$

$S=\left(\pi / 2 \cos ^{2} \theta_{C}\right)\left\{d^{2} \cos ^{2} \theta_{C}+4\left(H_{B}-d / 2\right)^{2} \cos \theta_{C}\right.$

$-4\left(H_{B}-d / 2\right)^{2} \sin ^{-1}\left(\cos \theta_{C}\right)$

$\left.+2 d\left(H_{B}-d / 2\right) \cos \theta_{C} \sin ^{-1}\left(\cos \theta_{C}\right)\right\}$

$A=\left(\pi / 4 \cos ^{2} \theta_{C}\right)\left\{4\left(H_{B}-d / 2\right)^{2} \sin ^{2} \theta_{C}-8\left(H_{B}-d / 2\right)^{2} \sin \theta_{C}\right.$

$+4 d\left(H_{B}-d / 2\right) \sin \theta_{C} \cos \theta_{C}+4\left(H_{B}-d / 2\right)^{2}$

$\left.-4 d\left(H_{B}-d / 2\right) \cos \theta_{C}+d^{2} \cos ^{2} \theta_{C}\right\}$

$z_{G}=\pi\left[\left(d^{4} / 64\right)+\left(1 / 24 \cos ^{4} \theta_{C}\right)\left\{16\left(H_{B}-d / 2\right)^{4}\right.\right.$

$-8 d\left(H_{B}-d / 2\right)^{3} \cos \theta_{C}-24\left(H_{B}-d / 2\right)^{4} \cos ^{2} \theta_{C}$

$+12 d\left(H_{B}-d / 2\right)^{3} \cos ^{3} \theta_{C}-3 d^{2}\left(H_{B}-d / 2\right)^{2} \cos ^{4} \theta_{C}$

$+6\left(H_{B}-d / 2\right)^{4} \cos ^{4} \theta_{C}-16\left(H_{B}-d / 2\right)^{4} \sin ^{3} \theta_{C}$

$\left.\left.+8 d\left(H_{B}-d / 2\right)^{3} \sin ^{3} \theta_{C} \cos \theta_{C}\right\}\right] / V_{B}+\left(H_{B}-d / 2\right)$.

(3) モデル3 (Fig. 4(c) 参照)：円錐台の上に円柱が, さら にその上に半球が乗った形状。「付録-3：式 (10)〜(13)の導出」を参照。

$V_{B}=(\pi / 12)\left\{d^{3}+3 d^{2}\left(H_{B}-d / 2\right)\left(1+\cos \theta_{C}\right)-12\left(H_{B}-d / 2\right)^{3} \cos \theta_{C}\right.$

$-12 H_{B}^{2}\left(H_{B}-d / 2\right) \cos \theta_{C}+4\left(H_{B}-d / 2\right)^{3} \cos ^{3} \theta_{C}$ 


$$
\begin{aligned}
& +12 H_{B}\left(H_{B}-d / 2\right)^{2} \sin \theta_{C} \cos \theta_{C} \\
& \left.+12 H_{B}\left(H_{B}-d / 2\right)^{2} \sin ^{-1}\left(\cos \theta_{C}\right)\right\} \\
& S=(\pi / 2)\left\{d^{2}+2 d\left(H_{B}-d / 2\right)\left(1+\cos \theta_{C}\right)+4\left(H_{B}-d / 2\right)^{2} \cos \theta_{C}\right. \\
& \left.-4 H_{B}\left(H_{B}-d / 2\right) \sin ^{-1}\left(\cos \theta_{C}\right)\right\} \\
& A=\pi\left\{\left(H_{B}-d / 2\right)^{2} \sin ^{2} \theta_{C}+2 H_{B}\left(H_{B}-d / 2\right) \sin \theta_{C}+H_{B}{ }^{2}\right\} \cdots \\
& z_{G}=\pi\left[\left(d^{3} / 12\right)\left\{\left(H_{B}-d / 2\right)\left(1+\cos \theta_{C}\right)+3 d / 16\right\}\right. \\
& +\left(d^{2} / 8\right)\left(H_{B}-d / 2\right)^{2}\left(1+\cos \theta_{C}\right)^{2}+(1 / 12)\left\{8 H_{B}\left(H_{B}-d / 2\right)^{3}\right. \\
& -6\left(H_{B}-d / 2\right)^{4} \cos ^{2} \theta_{C}+3\left(H_{B}-d / 2\right)^{4} \cos ^{4} \theta_{C} \\
& \left.\left.-8 H_{B}\left(H_{B}-d / 2\right)^{3} \sin ^{3} \theta_{C}-6 H_{B}{ }^{2}\left(H_{B}-d / 2\right)^{2} \cos ^{2} \theta_{C}\right\}\right] / V_{B} \\
& -\left(H_{B}-d / 2\right) \cos \theta_{C}
\end{aligned}
$$

(4) モデル4（Fig. 4(d) 参照)：円錐台の上に回転楕円体の 半分が乗った形状。「付録 -4 : 式 (14) (17) の導出」 を参照。

$$
\begin{aligned}
& V_{B}=\left(\pi / 3 \cos ^{3} \theta_{C}\right)\left\{2 a^{2} b \cos ^{3} \theta_{C}+6 k^{3} b^{3} \cos \theta_{C}-6 k^{2} a b^{2} \cos ^{2} \theta_{C}\right. \\
& +3 k a^{2} b \cos ^{3} \theta_{C}-k^{3} b^{3} \cos ^{3} \theta_{C}-3 k^{3} b^{3} \sin \theta_{C} \cos \theta_{C} \\
& -3 k^{3} b^{3} \sin ^{-1}\left(\cos \theta_{C}\right)+3 k^{2} a b^{2} \sin \theta_{C} \cos ^{2} \theta_{C} \\
& \left.+3 k^{2} a b^{2} \cos \theta_{C} \sin ^{-1}\left(\cos \theta_{C}\right)\right\}
\end{aligned}
$$

[ $a>b$ のとき]

$$
\begin{aligned}
S= & \pi\left[a^{2}+\left\{a b^{2} / 2\left(a^{2}-b^{2}\right)^{1 / 2}\right\} \log _{e}\left[\left\{a+\left(a^{2}-b^{2}\right)^{1 / 2}\right\} /\right.\right. \\
& \left.\left\{a-\left(a^{2}-b^{2}\right)^{1 / 2}\right\}\right]+\left(2 / \cos ^{2} \theta_{C}\right)\left\{k^{2} b^{2} \cos \theta_{C}\right. \\
& \left.\left.-k^{2} b^{2} \sin ^{-1}\left(\cos \theta_{C}\right)+k a b \cos \theta_{C} \sin ^{-1}\left(\cos \theta_{C}\right)\right\}\right]
\end{aligned}
$$

$$
[a<b \text { とき] }
$$$$
S=\pi\left[a^{2}+\left\{a b^{2} /\left(b^{2}-a^{2}\right)^{1 / 2}\right\} \cos ^{-1}(a / b)\right.
$$$$
+\left(2 / \cos ^{2} \theta_{C}\right)\left\{k^{2} b^{2} \cos \theta_{C}-k^{2} b^{2} \sin ^{-1}\left(\cos \theta_{C}\right)\right.
$$$$
\left.\left.+k a b \cos \theta_{C} \sin ^{-1}\left(\cos \theta_{C}\right)\right\}\right]
$$

$A=\left(\pi / \cos ^{2} \theta_{C}\right)\left(k^{2} b^{2} \sin ^{2} \theta_{C}-2 k^{2} b^{2} \sin \theta_{C}+2 a b k \sin \theta_{C} \cos \theta_{C}\right.$

$$
\left.+k^{2} b^{2}-2 a b k \cos \theta_{C}+a^{2} \cos ^{2} \theta_{C}\right)
$$

$z_{G}=\pi\left[a^{2} b^{2} / 4+\left(1 / 12 \cos ^{4} \theta_{C}\right)\left\{8 k^{4} b^{4}-8 k^{3} a b^{3} \cos \theta_{C}\right.\right.$

$-12 k^{4} b^{4} \cos ^{2} \theta_{C}+12 k^{3} a b^{3} \cos ^{3} \theta_{C}-6 k^{2} a^{2} b^{2} \cos ^{4} \theta_{C}$

$+3 k^{4} b^{4} \cos ^{4} \theta_{C}-8 k^{4} b^{4} \sin ^{3} \theta_{C}$

$\left.\left.+8 k^{3} a b^{3} \sin ^{3} \theta_{C} \cos \theta_{C}\right\}\right] / V_{B}+k b$

（5）モデル 5 (Fig. 4(e)参照)：円柱の上に回転棈円体の半 分が乗った形状。「付録 -5 : 式 (18), (21) の導出」を 参照。

$$
V_{B}=\pi a^{2} b(2+3 k) / 3
$$

$$
[a>b \text { とき }]
$$$$
S=\pi\left[2 k a b+a^{2}+\left\{a b^{2} / 2\left(a^{2}-b^{2}\right)^{1 / 2}\right\} \log _{e}\left[\left\{a+\left(a^{2}-b^{2}\right)^{1 / 2}\right\}\right.\right.
$$

$$
\left.\left./\left\{a-\left(a^{2}-b^{2}\right)^{1 / 2}\right\}\right]\right]
$$

$[a<b$ のき $]$

$$
\begin{aligned}
& S=\pi\left[2 k a b+a^{2}+\left\{a b^{2} /\left(b^{2}-a^{2}\right)^{1 / 2}\right\} \cos ^{-1}(a / b)\right] \\
& A=\pi a^{2} \\
& z_{G}=3\left(-2 k^{2}+1\right) b / 4(2+3 k)+k b
\end{aligned}
$$

なお，モデル 4, モデル 5 については簡単化のために $k$ の值を 1 として評価した。

\section{$3 \cdot 2$ 力のバランス式を考慮した離脱直前気泡の体積予測}

今回用いたモデルでは Fig. 5 に示すように気泡形状の予 測曲線が 3 タイプ見られた。すなわち, 気泡体積 $V_{B}$ の増加 に伴いある体積でエネルギー $E$ が極小值をもたなくなる(1) タイプ， $V_{B}$ の広い範囲で $E$ が極小值をもつ(2)タイプ，さ らにある $V_{B}$ から $E$ が極小值をもちはじめる(3)タイプであ る。ここで, (1)タイプの場合， $E$ が極小值をもたなくなる $V_{B}$ で気泡は不安定になり，固体に付着していることがで きないと考えられる。事実, 水一空気系でモデル 1,3 を適 用した接触角 $\theta_{C}$ が小さい場合 $\left(\theta_{C}=96^{\circ}\right)$ では, この考えか ら求めた離脱直前気泡の体積は実測值と比較的良く合って いる。しかしながら， $\theta_{C}$ の広い範囲で形状予測に適用で きるモデル 2,4 は (2), (3) タイプであり，この方法による離 脱直前気泡の体積予測はできない。そこでエネルギー式に 加えて力のバランス式を考慮した。すなわち, 気泡に働く 浮力が固気界面張力の鉛直成分より大きくなるときの体積 を離脱体積とした。この条件は次式で表される。

$$
\left(\rho_{L}-\rho_{g}\right) g V_{B}>\pi D_{B} \sigma_{G L} \sin \theta_{C}
$$

本研究では便宜上 $A_{B}-V_{B}$ 曲線において式 (22) の左辺と 右辺が等しくなるときの体積を離脱直前気泡体積の予測值 $V_{B s, c a l .}$ とした。

\section{3 -3 ポテンシャル法による気泡形状, 離脱体積の予測値 とラプラス法との比較}

\section{$3 \cdot 3 \cdot 1$ 気泡形状}

Fig. 6, 7,8,9 に水一空気系における接触角 $\theta_{C}$ がそれぞれ $96^{\circ}, 104^{\circ}, 116^{\circ}, 131^{\circ}$ の場合の気泡体積 $V_{B}$ に対するアスぺ クト比 $A_{B}$ の関係を示す。同様にFig.10 は水銀-空気系にお ける $\theta_{C}$ が $130^{\circ}$ の場合を示す。ここで, 細い線は各モデル を適用しエネルギー式に基づき求めた $A_{B}$ の予測值であり， 太い線はラプラス法による $A_{B}{ }^{22)}$ ，丸印は実測值を示す。殏 中の白丸印は離脱以前の小さい付着気泡を, また右寄りの 黒丸印は離脱直前の付着気泡を表す。ここで $\theta_{C}$ が $96^{\circ} の$ 実測值は以前に水-空気系鉛直気泡噴流中に濡れ性の悪い 四角柱を水平に置いた場合の四角柱への気泡付着のメカニ ズムを検討した際のものである。

今回用いた 5 種類のモデルのうち, $V_{B}$ の広い範囲で $A_{B}$ の予測值を与えるものはモデル 4,5 であった。ここで, 水 -空気系でのモデル 4 による $A_{B}$ の予測值のラプラス法に対 する偏差は $-1 \%$ + $35 \%$ であり，モデル 5 では $-5 \%$ 


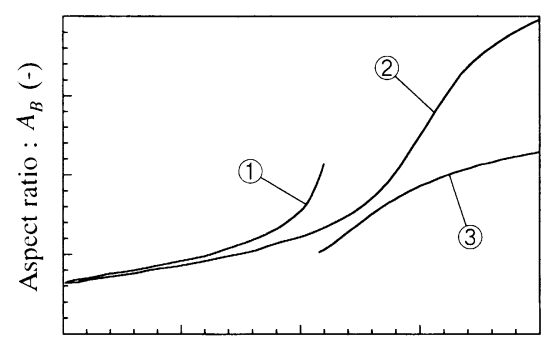

Volume : $V_{B}\left(\mathrm{~m}^{3}\right)$

Fig. 5. Relation between $A_{B}$ and $V_{B}$ when bubble energy is minimum.

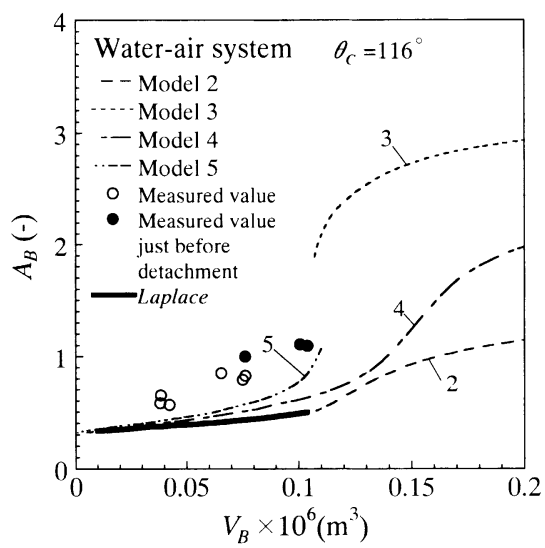

Fig. 8. Comparison of $A_{B}$ between measured and calculated values at $\theta_{C}$ of 116 degrees in water-air system.

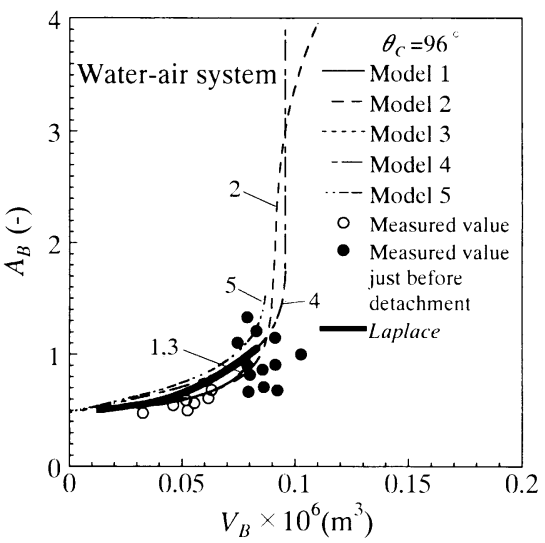

Fig. 6. Comparison of $A_{B}$ between measured and calculated values at $\theta_{C}$ of 96 degrees in water-air system.

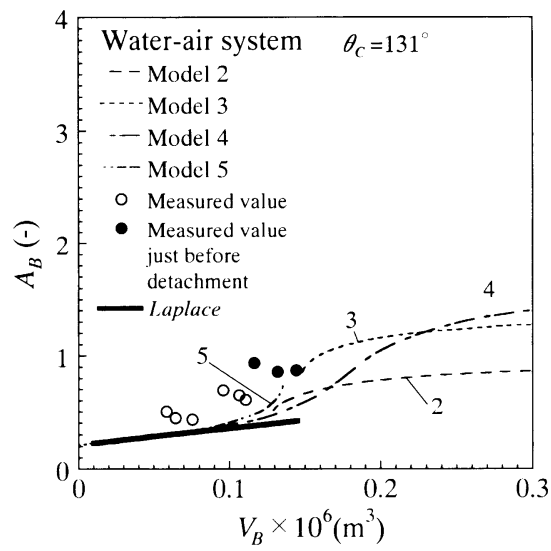

Fig. 9. Comparison of $A_{B}$ between measured and calculated values at $\theta_{C}$ of 131 degrees in water-air system.

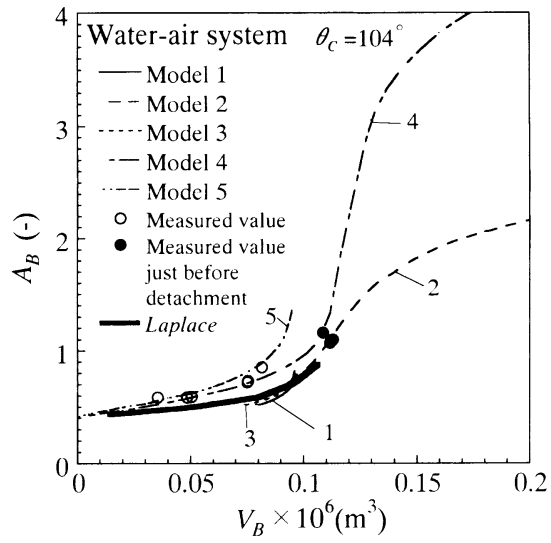

Fig. 7. Comparison of $A_{B}$ between measured and calculated values at $\theta_{C}$ of 104 degrees in water-air system.

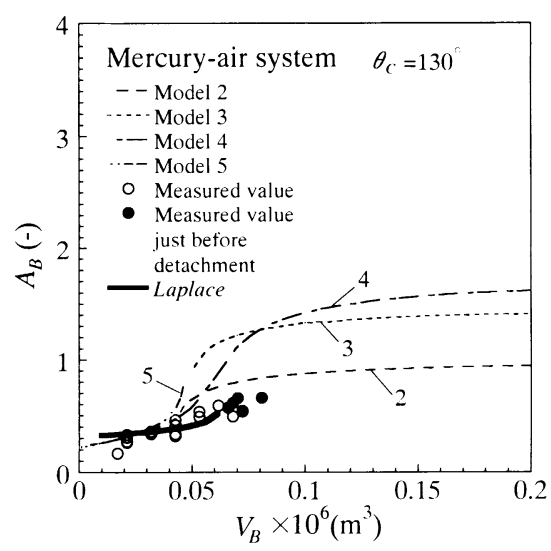

Fig. 10. Comparison of $A_{B}$ between measured and calculated values at $\theta_{C}$ of 130 degrees in mercury-air system.
$+85 \%$ と偏差が大きいためモデル 4 が最も良いと判断した。 ただし，水銀一空気系ではモデル4でもラプラス法に対し て - 20\%〜+70\%の偏差があった。この偏差はモデルの工 夫により小さくできるがモデルが煩雑になることや，以下 にも示すように, 現状モデル 4 でも離脱直前気泡体積 $V_{B s}$ の予測に対しては $-27 \%$ + $18 \%$ の偏差であり，満足でき る精度が得られることを考慮して，今回はモデル 4 で検討 を進める。

\section{$3 \cdot 3 \cdot 2$ 離脱体積}

次に Fig.11には，モデル 4 を適用し，3·2で述べたよう に力のバランス式を考慮して求めた離脱直前気泡体積の予 測值 $V_{B s, \text { cal. }}$ とラプラス法から求められた体積 ${ }^{11)}$ を各接触角 $\theta_{C}$ に対して示す。ここでは参考のため溶鉄-アルゴン系に ついても記載した。罒から $\theta_{C}$ が実用上重要であると考え られる $94^{\circ}$ から $130^{\circ}$ の範囲における，モデル4による予測 值は 3 種類の実験系の違いにかかわらずラプラス法に対す る偏差は $-27 \%$ + $18 \%$ であった。前述の $A_{B}$ の予測精度は ともかくとして，離脱体積に重点をおく本研究では，この
程度のばらつき範囲であればモデルの精度は十分であると 判断した。

Fig.11に示した3種類の系に対する計算結果を系統的に まとめることが可能であるかどうかをボンド数 $B$ に着目し て検討する。

$$
B=g l^{2}\left(\rho_{L}-\rho_{g}\right) / \sigma_{G L}
$$

ここで $l$ は気泡の代表長さであり, 本研究では $l$ として離 脱気泡の球相当直径を採用する。

$$
l=\left[6 V_{B s} / \pi\right]^{1 / 3}
$$

なお $B$ は気泡に働く浮力と表面張力による力との比を表 す。

ラプラス法による離脱気泡体積から求めたボンド数 $B$ の 值はFig.12 に示すようによくまとめられる。また，モデル 4 による $B$ の值も Fig.11 から予想されるようにラプラス法

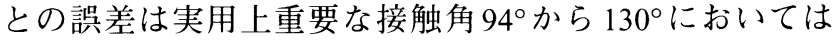
$-19 \%$ + $11 \%$ の範囲にあり，系の種類にかかわらずモデ 


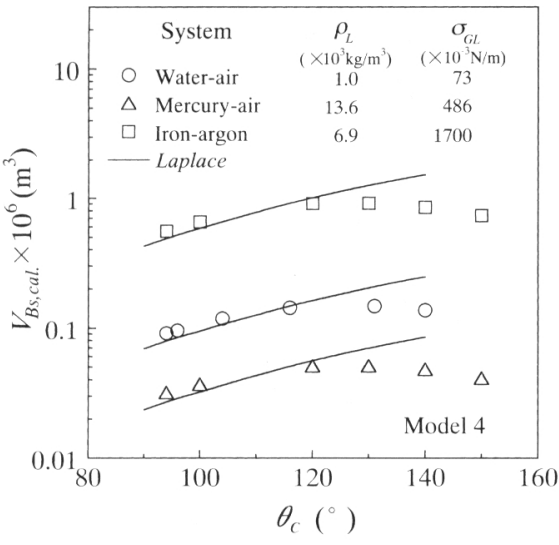

Fig. 11. Comparison of $V_{B s}$ between present method and previous method by Laplace.

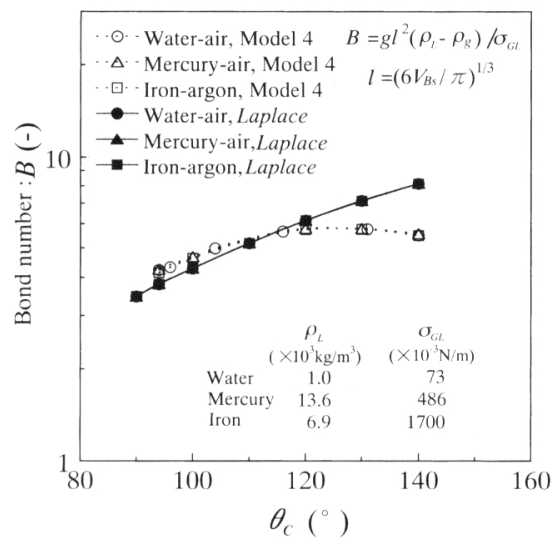

Fig. 12. Comparison of $B$ between present method and previous method by Laplace.

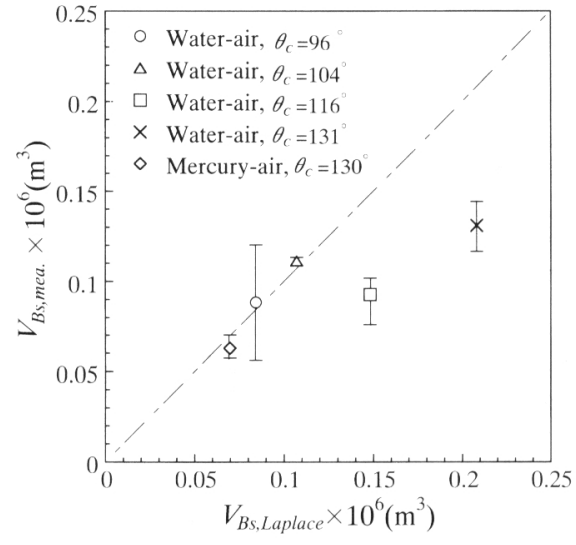

Fig. 13. Comparison of $V_{B s}$ between measured and calculated values.
ル 4 が近似的に適用できる。したがって，気泡周りの流れ 場の影響などを議論する際に，モデル4を適用してもよい と結論できよう。

\section{4 気泡形状, 離脱体積の実測值とラプラス法との比較}

Fig. 6, 7,8，9，10 に打いてアスペクト比 $A_{B}$ の実測值をラ プラス法 ${ }^{12)}$ と比較したところ $-40 \%$ + $100 \%$ の偏差が あった。また，Fig.13 に示すように離脱直前気泡体積の実 測值 $V_{B S \text {, mea }}$ をラプラス法による体積 $V_{B S \text {, Laplace }}{ }^{11)}$ と比較し たところ $-37 \%$ + $5 \%$ の偏差があった。このばらつきを見 ると $A_{B}, V_{B S}$ ともラプラス法と大きくずれる測定条件は $\theta_{C}$ が大きい場合であった。この理由は以下のように考えられ る

まず，水一空気系の気泡体積 $V_{B}$ の実測值は気泡の外形を 読及取り，回転体として体積を評価している。したがって $\theta_{C}$ が $96^{\circ}$ のきの $V_{B}$ の測定誤差は文献 ${ }^{8)}$ に示すように 土21\%であるが， $\theta_{C}$ が大きくなると匃泡のすその部分の わずかな読み取り䛊差によって体積䛊差はさらに大きくな る。この体積測定䛊差が影響したと考えられる。

次に，水一空父系で $\theta_{C}$ が大きい場合の $A_{B}, V_{B S}$ の予測值 とラプラス法とのずれは, Fig. 8,9，13 に示すように，気 泡が水平方向に広がりにくく垂直方向にのびたと仮定する とよく説明できる。すなわち，本夹験のように空気をゆっ くりと送り込む采でも, 水のように表面張力が小さい場合, 気泡は体積が大きくなると厳密な静止状態を保てず，わず かな外部からの擾乱の影響で不安定となり，十分水平方向 に広がる以前に離脱することが予想される。このことは， $\theta_{C}$ が大きくとも表面張力が大きい水銀一空気系では $V_{B S}$ の 偏差がー10\%と小さいことからも裏付けられる。

さらに，ポテンシャル法とラプラス法の計算結果を比較 する際には問題ないが, 測定值とこれらの計算值を比較す るに際しては，接触角にどのような值を採用するのかと いった点が問題となる。本研究では液滴法によって求めた 平衡接触角を用いているが, 液滴法で求めた接触角がこの 場合のような表面粗さを無視できない平板に対してそのま

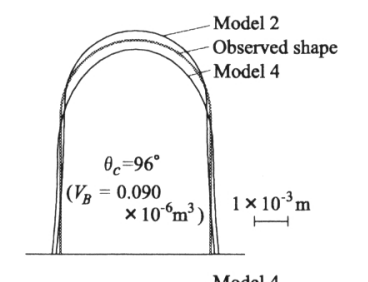

\section{Water-air system}
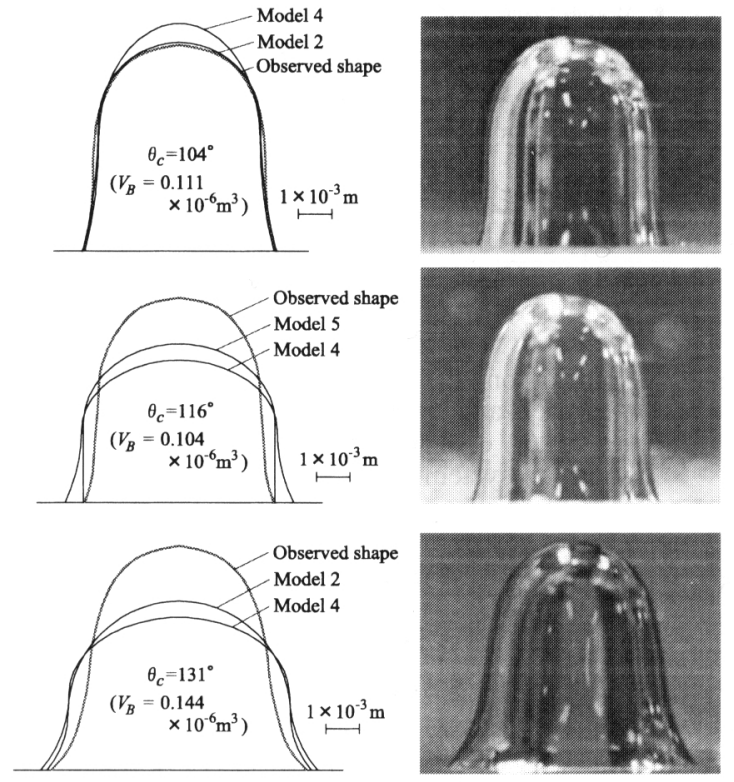

Fig. 14. Observed and calculated bubble shapes in waterair system.

ま適用できるかといった点も含めて, 実験結果と計算結果 との不一致の理由については今後の課題としたい。

なお，本研究での $D_{B}$ の実測值 $6.5 \times 10^{-3} \mathrm{~m}$ は，小沢ら ${ }^{15)}$ により報告された，水銀浴への低流量窒素ガス吹込みにお ける気泡の幹直径 $D_{B}$ の最大值 $6.5 \times 10^{-3} \mathrm{~m}$ と一致してい る。

また，参考として Fig.14，15にそれぞれ水一空気系，水 銀一空気系での各 $\theta_{C}$ における代表的な央測気泡の写真と その体積をモデルに代人して得られた気泡の形状を示す。 


\section{Mercury-air system}
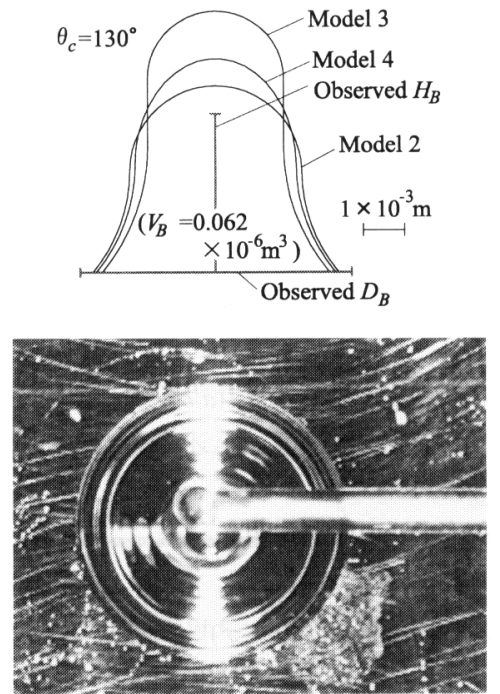

Fig. 15. Observed and calculated bubble shapes in mercury-air system.

\section{4. 結論}

水打よび水銀中の微細な空気気泡を濡れ性の悪い固体へ 付着させてその体積を增加させ，浮力により除去する操作 において，微細気泡をどの程度の大きさにできるかを明ら かにするために，液体中へ水平に置いた平板上に付着する 気泡の体積増加に伴う離脱までの挙動を $\mathrm{CCD}$ カメラ等で 観察した。得られた主な結論は以下のと打りである。

（1）濡机性の悪い平板上に留まることのできる気泡体 積は，Fig.12 に示すようにボンド数 $B$ を用いることによっ て系統的に整理できる。また, 気泡の形状に簡便なモデル 4者適用し, 気泡のもつエネルギーと気泡に働く力のバラ ンスを考虑して近似的に求めた結果は, ラプラス法から求 められたボンド数の值 ${ }^{11)}$ に対して Fig.12 に示すように， 実用上重要な接触角 $94^{\circ}$ から $130^{\circ} に$ にいてはー19\%〜 $+11 \%$ の範囲内にあり，十分な予測精度であった。

（2）エネルギー式を用いた付着気泡の形状と寸法の予 測は, 離脱以前の体積の小さい気泡に刘しても適用でき る。

（3）気泡の形状と寸法の予測の性能を総合的に判断し て，今回用いた 5 種類のモデルのうち，モデル 4 が有効で ある。

本研究は日本鉄鋼協会の「鉄鋼研究振興助成」を受けた。 ここに記して感謝の意を表する。

\section{文献}

1) K.Ito and R.J.Fruehan: Metall.Trans. B, 20B (1989), 515

2 ) S.S.Ghag, P.C.Hayes and H.-G.Lee: ISIJ Int., 38 (1998), 1208

3 ) L.Hong, M.Hirasawa and M.Sano: ISIJ Int., 38 (1998), 1339.

4 ) M.Matsuo, H.Hirata, H.Katayama, H.Ishikawa, H.Kajioka and N.Tokumitsu: Tetsu-to-Hagané, 72 (1986), S970.
5) K.Ito and R.J.Fruehan: Metall.Trans. B, 20B (1989), 509.

6 ) S.V.Komarov, M.Kuwabara and M.Sano: CAMP-ISIJ, 12 (1999), 721

7) Y.Ogawa and N.Tokumitsu: Proc. of 6th Int. Iron and Steel Cong. (6th IISC), ISIJ, Tokyo, (1990), 147.

8) Y.Mizuno, T.Shimizu, N.Sonoyama and M.Iguchi: Jpn. J. Multiphase Flow, 14 (2000), 166.

9) N.Sonoyama, M.Iguchi, Y.Sasaki and K.Ishii: Tetsu-to-Hagané, 86 (2000), 203.

10) C.Lee, I.Takahashi and H.Miyata: Trans. Jpn. Soc. Mech. Eng. (B), 61 (1995), 4386

11) W.Fritz: Physik. Zeitschr., 36 (1935), 379.

12) F.Bashforth and J.C.Adams: An Attempt to Test the Theories of Capillary Action, Cambridge Univ. Press, Cambridge, (1883).

13) M.Sano, K.Mori and T.Sato: Tetsu-to-Hagané, 63 (1977), 2308.

14) K.Murakami, T.Sunada and N.Ueki: Trans. Jpn. Soc. Mech. Eng. (B), 64 (1998), 2071

15) Y.Ozawa, K.Mori and M.Sano: Tetsu-to-Hagané, 16 (1981), 2655.

\section{付 録}

付録-1：式( 2 ), ( 3 ), ( 5 ) の導出

$$
\begin{aligned}
& V_{B}=\pi D_{B}{ }^{3} / 12+\pi D_{B}{ }^{2}\left(H_{B}-D_{B} / 2\right) / 4 \\
& S=\pi D_{B}{ }^{2} / 2+\pi D_{B}\left(H_{B}-D_{B} / 2\right) \\
& z_{G}=\left(M_{1}+M_{(2)}\right) / V_{B}+\left(H_{B}-D_{B} / 2\right) \\
& \text { ここで, } M \text { は } x \text { 軸周りのモーメントを表す。 } \\
& M_{1}=(3 / 8)\left(D_{B} / 2\right)\left(\pi D_{B}{ }^{3} / 12\right) \\
& M_{2}=-(1 / 2)\left(H_{B}-D_{B} / 2\right)\left\{\pi D_{B}{ }^{2}\left(H_{B}-D_{B} / 2\right) / 4\right\}
\end{aligned}
$$

付録 -2 : 式 (6) ( 9 )の導出

$$
\begin{aligned}
V_{B}= & \pi d^{3} / 12+\pi \int_{-\left(H_{B}-d / 2\right)}^{0} x^{2} \mathrm{~d} z \\
= & \pi d^{3} / 12+\pi \int_{-\left(H_{B}-d / 2\right)}^{0}\left\{\left(r^{2}-z^{2}\right)-2(r+d / 2)\left(r^{2}-z^{2}\right)^{1 / 2}+(r+d / 2)^{2}\right\} \mathrm{d} z \\
= & \pi d^{3} / 12+\pi\left[r^{2} z-z^{3} / 3-2(r+d / 2)\left\{(z / 2)\left(r^{2}-z^{2}\right)^{1 / 2}+\left(r^{2} / 2\right) \sin ^{-1}(z / r)\right\}\right. \\
& \left.+(r+d / 2)^{2} z\right]_{-\left(H_{B}-d / 2\right)}^{0}
\end{aligned}
$$$$
S=\pi d^{2} / 2+2 \pi \int_{-\left(H_{B}-d / 2\right)}^{0} x\left\{1+(\mathrm{d} x / \mathrm{d} z)^{2}\right\}^{1 / 2} \mathrm{~d} z
$$$$
=\pi d^{2} / 2+2 \pi \int_{-\left(H_{B}-d / 2\right)}^{0}\left\{-r+r(r+d / 2) /\left(r^{2}-z^{2}\right)^{1 / 2}\right\} \mathrm{d} z
$$$$
=\pi d^{2} / 2+2 \pi\left[-r z+r(r+d / 2) \sin ^{-1}(z / r)\right]_{-\left(H_{B}-d / 2\right)}^{0}
$$$$
A=\pi x^{2}\left[z=-\left(H_{B}-d / 2\right) \text { のとき }\right]
$$$$
=\pi\left\{\left(r^{2}-z^{2}\right)-2(r+d / 2)\left(r^{2}-z^{2}\right)^{1 / 2}+(r+d / 2)^{2}\right\}
$$$$
=\pi\left[r^{2}-\left(H_{B}-d / 2\right)^{2}-2(r+d / 2)\left\{r^{2}-\left(H_{B}-d / 2\right)^{2}\right\}^{1 / 2}+(r+d / 2)^{2}\right]
$$$$
z_{G}=\left(M_{(1)}+M_{(2)}\right) / V_{B}+\left(H_{B}-d / 2\right)
$$$$
M_{\mathbb{1}}=(3 / 8)(d / 2)\left(\pi d^{3} / 12\right)=\pi d^{4} / 64
$$$$
M_{(2)}=\pi \int_{-\left(H_{p}-d / 2\right)}^{0} z x^{2} \mathrm{~d} z
$$

$$
\begin{aligned}
z_{G}= & \left\{\left(\pi d^{4} / 64\right)+\pi \int_{-\left(H_{B}-d / 2\right)}^{0} z x^{2} \mathrm{~d} z\right\} / V_{B}+\left(H_{B}-d / 2\right) \\
= & {\left[\left(\pi d^{4} / 64\right)+\pi \int_{-\left(H_{B}-d / 2\right)}^{0} z\left\{\left(r^{2}-z^{2}\right)-2(r+d / 2)\left(r^{2}-z^{2}\right)^{1 / 2}\right.\right.} \\
& \left.\left.+(r+d / 2)^{2}\right\} \mathrm{~d} z\right] / V_{B}+\left(H_{B}-d / 2\right)
\end{aligned}
$$




$$
\begin{aligned}
= & {\left[\left(\pi d^{4} / 64\right)+\pi \int_{-\left(H_{B}-d / 2\right)}^{0}\left\{r^{2} z-z^{3}-2(r+d / 2) z\left(r^{2}-z^{2}\right)^{1 / 2}\right.\right.} \\
& \left.\left.+(r+d / 2)^{2} z\right\} \mathrm{~d} z\right] / V_{B}+\left(H_{B}-d / 2\right) \\
= & {\left[\left(\pi d^{4} / 64\right)+\pi\left[r^{2} z^{2} / 2-z^{4} / 4+(2 / 3)(r+d / 2)\left(r^{2}-z^{2}\right)^{3 / 2}\right.\right.} \\
& \left.\left.+(r+d / 2)^{2} z^{2} / 2\right]_{-\left(H_{B}-d / 2\right)}^{0}\right] / V_{B}+\left(H_{B}-d / 2\right)
\end{aligned}
$$

付録 $-3:$ 式 (10) (13)の導出

$$
\begin{aligned}
& V_{B}=\pi d^{3} / 12+\pi d^{2} b / 4+\pi \int_{-a}^{0} x^{2} \mathrm{~d} z \\
& =\pi d^{3} / 12+\pi d^{2} b / 4+\pi \int_{\left(H_{B}-d / 2\right) \cos \theta_{C}}^{0}\left\{\left(r^{2}-z^{2}\right)-2(r+d / 2)\left(r^{2}-z^{2}\right)^{1 / 2}\right. \\
& \left.+(r+d / 2)^{2}\right\} \mathrm{d} z \\
& =\pi d^{3} / 12+\pi d^{2} b / 4+\pi\left[r^{2} z-z^{3} / 3-2(r+d / 2)\left\{(z / 2)\left(r^{2}-z^{2}\right)^{1 / 2}\right.\right. \\
& \left.\left.+\left(r^{2} / 2\right) \sin ^{-1}(z / r)\right\}+(r+d / 2)^{2} z\right]_{\left(H_{B}-d / 2\right) \cos \theta_{c}}^{0} \\
& S=\pi d^{2} / 2+\pi d b+2 \pi \int_{-a}^{0} x\left\{1+(\mathrm{d} x / \mathrm{d} z)^{2}\right\}^{1 / 2} \mathrm{~d} z \\
& =\pi d^{2} / 2+\pi d b+2 \pi \int_{\left(H_{B}-d / 2\right) \cos \theta_{c}}^{0}\left\{-r+r(r+d / 2) /\left(r^{2}-z^{2}\right)^{1 / 2}\right\} \mathrm{d} z \\
& =\pi d^{2} / 2+\pi d b+2 \pi\left[-r z+r(r+d / 2) \sin ^{-1}(z / r)\right]_{\left(H_{B}-d / 2\right) \cos \theta_{c}}^{0} \\
& A=\pi x^{2}\left[z=\left(H_{B}-d / 2\right) \cos \theta_{C} \text { のとき }\right] \\
& =\pi\left\{\left(r^{2}-z^{2}\right)-2(r+d / 2)\left(r^{2}-z^{2}\right)^{1 / 2}+(r+d / 2)^{2}\right\} \\
& =\pi\left[r^{2}-\left(H_{B}-d / 2\right)^{2} \cos ^{2} \theta_{C}-2(r+d / 2)\left\{r^{2}-\left(H_{B}-d / 2\right)^{2} \cos ^{2} \theta_{C}\right\}^{1 / 2}\right. \\
& \left.+(r+d / 2)^{2}\right] \\
& z_{G}=\left(M_{\mathbb{1}}+M_{(2)}+M_{(3)}\right) / V_{B}+a \\
& M_{1}=\{b+(3 / 8)(d / 2)\}\left(\pi d^{3} / 12\right) \\
& =\left(\pi d^{3} / 12\right)\left\{\left(H_{B}-d / 2\right)\left(1+\cos \theta_{C}\right)+3 d / 16\right\} \\
& M_{\text {(2) }}=(b / 2)\left(\pi d^{2} b / 4\right)=\left(\pi d^{2} / 8\right)\left(H_{B}-d / 2\right)^{2}\left(1+\cos \theta_{C}\right)^{2} \\
& M_{\text {(3) }}=\pi \int_{-a}^{0} z x^{2} \mathrm{~d} z \\
& =\pi \int_{\left(H_{B}-d / 2\right) \cos \theta_{c}}^{0} z\left\{\left(r^{2}-z^{2}\right)-2(r+d / 2)\left(r^{2}-z^{2}\right)^{1 / 2}+(r+d / 2)^{2}\right\} \mathrm{d} z \\
& =\pi\left[r^{2} z^{2} / 2-z^{4} / 4+(2 / 3)(r+d / 2)\left(r^{2}-z^{2}\right)^{3 / 2}\right. \\
& \left.+(r+d / 2)^{2} z^{2} / 2\right]_{\left(H_{B}-d / 2\right) \cos \theta_{c}}^{0} \\
& =(\pi / 12)\left\{8 H_{B}\left(H_{B}-d / 2\right)^{3}-6\left(H_{B}-d / 2\right)^{4} \cos ^{2} \theta_{C}\right. \\
& +3\left(H_{B}-d / 2\right)^{4} \cos ^{4} \theta_{C}-8 H_{B}\left(H_{B}-d / 2\right)^{3} \sin ^{3} \theta_{C} \\
& \left.-6 H_{B}^{2}\left(H_{B}-d / 2\right)^{2} \cos ^{2} \theta_{C}\right\}
\end{aligned}
$$

付録 $-4:$ 式 (14) (17) の導出

$$
V_{B}=2 \pi a^{2} b / 3+\pi \int_{-k b}^{0} x^{2} \mathrm{~d} z
$$

$$
\begin{aligned}
= & 2 \pi a^{2} b / 3+\pi \int_{-k b}^{0}\left\{\left(r^{2}-z^{2}\right)-2(r+a)\left(r^{2}-z^{2}\right)^{1 / 2}+(r+a)^{2}\right\} \mathrm{d} z \\
= & 2 \pi a^{2} b / 3 \\
& +\pi\left[r^{2} z-z^{3} / 3-2(r+a)\left\{(z / 2)\left(r^{2}-z^{2}\right)^{1 / 2}+\left(r^{2} / 2\right) \sin ^{-1}(z / r)\right\}\right. \\
& \left.+(r+a)^{2} z\right]_{-k b}^{0} \\
S= & S_{1}+S_{2}
\end{aligned}
$$

[ $a>b$ のとき]

$S_{1}=\pi\left[a^{2}+\left\{a b^{2} / 2\left(a^{2}-b^{2}\right)^{1 / 2}\right\} \log _{e}\left[\left\{a+\left(a^{2}-b^{2}\right)^{1 / 2}\right\} /\left\{a-\left(a^{2}-b^{2}\right)^{1 / 2}\right\}\right]\right]$ [ $a<b$ のとき]

$S_{1}=\pi\left[a^{2}+\left\{a b^{2} /\left(b^{2}-a^{2}\right)^{1 / 2}\right\} \cos ^{-1}(a / b)\right]$

また，

$$
\begin{aligned}
& S_{2}=2 \pi \int_{-k b}^{0} x\left\{1+(\mathrm{d} x / \mathrm{d} z)^{2}\right\}^{1 / 2} \mathrm{~d} z \\
& =2 \pi \int_{-k b}^{0}\left\{-r+r(r+a) /\left(r^{2}-z^{2}\right)^{1 / 2}\right\} \mathrm{d} z \\
& =2 \pi\left[-r z+r(r+a) \sin ^{-1}(z / r)\right]_{-k b}^{0} \\
& =\left(2 \pi / \cos ^{2} \theta_{C}\right)\left\{k^{2} b^{2} \cos \theta_{C}-k^{2} b^{2} \sin ^{-1}\left(\cos \theta_{C}\right)\right. \\
& \left.+k a b \cos \theta_{C} \sin ^{-1}\left(\cos \theta_{C}\right)\right\} \\
& A=\pi x^{2}[z=-k b \text { のとき }] \\
& =\pi\left\{\left(r^{2}-z^{2}\right)-2(r+a)\left(r^{2}-z^{2}\right)^{1 / 2}+(r+a)^{2}\right\} \\
& =\pi\left\{r^{2}-k^{2} b^{2}-2(r+a)\left(r^{2}-k^{2} b^{2}\right)^{1 / 2}+(r+a)^{2}\right\} \\
& z_{G}=\left(M_{1}+M_{(2)}\right) / V_{B}+k b \\
& M_{\mathbb{I}}=\pi \int_{0}^{b} z x^{2} \mathrm{~d} z=\left(a^{2} / b^{2}\right) \pi \int_{0}^{b} z\left(b^{2}-z^{2}\right) \mathrm{d} z=a^{2} b^{2} \pi / 4 \\
& M_{(2)}=\pi \int_{-k b}^{0} z x^{2} \mathrm{~d} z \\
& =\pi \int_{-k b}^{0} z\left\{\left(r^{2}-z^{2}\right)-2(r+a)\left(r^{2}-z^{2}\right)^{1 / 2}+(r+a)^{2}\right\} \mathrm{d} z \\
& =\pi\left[r^{2} z^{2} / 2-z^{4} / 4+(2 / 3)(r+a)\left(r^{2}-z^{2}\right)^{3 / 2}+(r+a)^{2} z^{2} / 2\right]_{-}^{0}{ }_{k b} \\
& =\left(\pi / 12 \cos ^{4} \theta_{C}\right)\left\{8 k^{4} b^{4}-8 k^{3} a b^{3} \cos \theta_{C}-12 k^{4} b^{4} \cos ^{2} \theta_{C}\right. \\
& +12 k^{3} a b^{3} \cos ^{3} \theta_{C}-6 k^{2} a^{2} b^{2} \cos ^{4} \theta_{C}+3 k^{4} b^{4} \cos ^{4} \theta_{C} \\
& \left.-8 k^{4} b^{4} \sin ^{3} \theta_{C}+8 k^{3} a b^{3} \sin ^{3} \theta_{C} \cos \theta_{C}\right\}
\end{aligned}
$$

付録 $-5:$ 式 (18), (21) の導出

$$
\begin{aligned}
& V_{B}=2 \pi a^{2} b / 3+\pi k a^{2} b \\
& z_{G}=\left(M_{1}+M_{(}\right) / V_{B}+k b \\
& M_{1}=(3 b / 8)\left(2 \pi a^{2} b / 3\right) \\
& M_{\odot}=(-k b / 2) \pi k a^{2} b
\end{aligned}
$$

